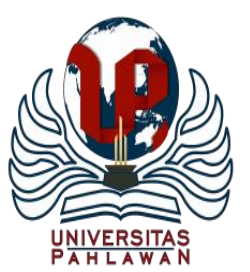

Jurnal Basicedu Volume 5 Nomor 1 Tahun 2021 Halaman 110-120 JURNAL BASICEDU

\author{
Research \& Learning in Elementary Education \\ https://jbasic.org/index.php/basicedu
}

\title{
Metode Multisensori untuk Siswa Disleksia di Sekolah Dasar
}

\author{
Asep Supena ${ }^{1}$, Indah Ratna Dewi ${ }^{2}$ \\ Universitas Negeri Jakarta, Indonesia ${ }^{1,2}$ \\ E-mail: supena2007@yahoo.com ${ }^{1} \underline{\text { cahayabt15@gmail.com }}^{2}$
}

\begin{abstract}
Abstrak
Problematika bagi sekolah dengan dasar pendidikan inklusi dimana hasil ketercapaian terhadap standar penilaian satuan pendidikan berada jauh dibawah rata-rata sekolah pada umumnya. Keberagaman karakteristik individu dengan berbagai kebutuhan khusus yang dimiliki setiap siswa pada sekolah dengan basik pendidikan inklusif menyebabkan satuan pendidikan harus mampu menemukan permasalahan yang dihadapi sehingga mampu memecahkan problematika dengan mengintegrasikan berbagai metode yang melibatkan seluruh panca indra dalam proses pembelajaran yang berlangsung agar mampu meningkatkan capaian terhadap standar penilaian satuan pendidikan pada sekolah berbasik pendidikan inklusi. Keberhasilan akademis pada satuan pendidikan dengan basik pendidikan inklusi memainkan peran integral dalam kehidupan anak-anak, yang mempengaruhi perkembangan dasar mereka. Namun, para guru masih banyak yang belum memahami ketidakmampuan belajar pada anak-anak disekolah dikarenakan kesulitan belajar yang disebabkan oleh disleksia. Guru hanya sedikit mengetahui apa itu disleksia yang dialami oleh anak-anak di sekolah yang menjadi faktor penyebab utama rendahnya capaian hasil belajar siswa. Dan guru hanya mengetahui sedikit tentang dampak yang diakibatkan oleh kesulitan belajar anak yang dikarenakan disleksia. Disleksia tidak hanya kesulitan menulis atau membaca sebuah kaliamat, namun disleksia merupakan hambatan belajar yang bersifat heterogen. Disleksia akan berdampak menyeluruh terhadap hasil belajar anak juga akan berdampak pada perkembangan Psikologis anak. Oleh karena itu, sangatlah penting bagi guru untuk menciptakan lingkungan belajar yang menyenangkan di mana siswa merasa senang untuk belajar dengan kesulitan yang dihadapinya. Dari hasil penelitian studi deskriptif didapatkan tiga temuan utama yang dapat dideskripsikan dalam penelitian ini berdasarkan hasil wawancara, observasi dan dokumentasi serta diperkuat dengan kajian teori dari berbagai referensi. Tiga kategori utama tersebut yaitu pertama metode multisensori mampu membantu meningkatkan hasil belajar siswa dengan karakteristik disleksia, kedua kondisi temuan di lapangan khususnya di SDN Marunda 02, ketiga solusi atau penanganan yang dapat dilakukan oleh guru dan orang tua dengan memberikan remedial untuk mengatasi kesulitan dan hambatan belajar yang dialami siswa berkebutuhan khusus dengan berbagai jenis disleksia.
\end{abstract}

Kata kunci: disleksia, metode multisensori, pendidikan inklusi

\section{Abstract}

The problem for schools with basic inclusive education is that the achievement results of the education unit assessment standards are far below the school average in general. The diversity of characteristics of individuals with various special needs that every student has in schools with basic inclusive education causes the education unit to be able to find problems that are faced so as to be able to solve problems by integrating various methods that involve all the five senses in the on going learning process in order to be able to increase the the achievement of educational unit assessment standards in inclusive educational units with basic inclusive education plays an integral role in children's lives, which affects their basic development. However, many teachers still do not understand learning disabilities in school children due to learning difficulties caused by dyslexia. Teachers know very little about dyslexia experienced by children in school which is the main factor causing the low student learning outcomes. And teachers know little about the impact caused by children's learning difficulties due to dyslexia. Dyslexia is not only difficult to write or read a sentence, but dyslexia is a heteregeneous learning barrier. Dyslexia will have a comprehensive impact on children's learning outcomes will also have an impact on psychological development child. Therefore, it is very important for teachers to create a pleasant learning environment where students feel happy to learn with the difficulties they face. From the results of descriptive study research, there are three main findings that can be described in this study based on the results of interviews, observations and documentation and strenghthened by theoretical studies from various refererences. The three main categories, namely the multisensory method can help improve student learning outcomes with dyslexia characteristics, the second is the finding conditions in the field, especially in SDN Marunda 02, the third is the solution or treatment that teachers and parents can do by providing remedials to overcome learning difficulties and obstacles. Experienced by students with special needs with various types of dyslexia.

Keywords: dyslexia, multisensory methods, inclusive education.

Copyright (c) 2021 Asep Supena, Indah Ratna Dewi

$\triangle$ Corresponding author

Address : Koja Jakarta Utara

Email : cahayabt15@gmail.com

Phone : :081806268305

DOI : https://doi.org/10.31004/basicedu.v5i1.623
ISSN 2580-3735 (Media Cetak)

ISSN 2580-1147 (Media Online) 


\section{PENDAHULUAN}

Kebijakan pemerintah dalam penuntasan wajib belajar pendidikan dasar sembilan tahun disemangati oleh seruan Internasional Educational For All (EFA) yang dikumandangkan UNESCO sebagai kesepakatan global hasil World Education Forum di Dakar, Sinegal tahun 2000. Seruan ini senapas dengan semangat jiwa pasal 31 UndangUndang Dasar 1945 tentang hak setiap warga negara untuk memperoleh pendidikan dan pasal 32 dan UU Nomor 20/2003 tentang Sistem Pendidikan Nasional yang mengatur mengenai pendidikan khusus dan pendidikan layanan khusus bagi peserta didik berkebutuhan khusus.

Di Indonesia melalui Keputusan Menteri Pendidikan dan Kebudayaan Nomor 002/U/1986 telah dirintis pengembangan sekolah penyelenggaraan pendidikan inklusif yang melayani penuntasan wajib belajar bagi peserta didik yang berkebutuhan khusus. Selama ini pendidikan bagi anak berkebutuhan khusus lebih banyak diselenggarakan secara segregasi di Sekolah Luar Biasa (SLB) dan Sekolah Dasar Luar Biasa (SDLB). Sementara itu, lokasi SLB dan SDLB pada umumnya berada di ibu kota/ kabupaten, padahal anak-anak berkebutuhan khusus banyak tersebar hampir di seluruh daerah (Kecamatan/Desa). Akibatnya sebagian anak berkebutuhan khusus tersebut tidak bersekolah karena lokasi SLB dan SDLB yang jauh dari tempat tinggalnya. Sementara kenyataan di lapangan menunjukkan bahwa program pendidikan anak berkebutuhan khusus yang terjadi di sekolah luar biasa ini masih sangat menekankan pada aspek pengajaran yang bersifat akademik, itupun dalam pelaksanaanya masih bersifat klasikal dan belum memperhitungkan perbedaan hambatan belajar anak secara individual. Padahal esensi pendidikan anak berkebutuhan khusus adalah bahwa pendidikan lebih bersifat individual karena perbedaan-perbedaan individu pada anak berkebutuhan khusus sangat mencolok. Bagi anak berkebutuhan khusus, sekurang-kurangnya diperlukan dua bidang kemadirian yang harus dimiliki, yaitu: (1) keterampilan dasar dalam hal membaca, menulis, komunikasi lisan, dan berhitung, (2) keterampilan perilaku adaptif, yaitu keterampilan mengurus diri dalam kehidupan sehari-hari (personal living skills), dan keterampilan menyesuaikan diri dengan lingkungan (social living skills).

Kesulitan belajar dapat dipahami melalui berbagai definisi yang dikemukakan oleh berbagai ahli dan asosiasi ahli kesulitan belajar. Reid(1986:12) mengemukakan pendapatnya bahwa kesulitan belajar biasanya tidak dapat diidentifikasi sampai anak mengalami kegagalan dalam menyelesaikan tugas-tugas akademik yang harus dilakukannya. Selanjutnya, ia mengatakan bahwa siswa yang diidentifikasi mengalami kesulitan belajar memiliki ciri-ciri, antara lain seperti berikut ini.

1. Memiliki tingkat intelegensi (IQ) normal, bahkan diatas normal, atau sedikit di bawah normal berdasarkan tes IQ. Namun, siswa yang memiliki IQ sedikit dibawah normal bukanlah karena IQ-nya yang dibawah normal, akan tetapi kesulitan belajar yang dialaminya menyebabkan ia mengalami 
kesulitan dalam menjalani tes IQ sehingga memperoleh skor yang rendah.

2. Mengalami kesulitan dalam beberapa mata pelajaran, tetapi menunjukkan nilai yang baik pada mata pelajaran yang lain.

3. Kesulitan belajar yang dialami siswa yang berkesulitan belajar berpengaruh terhadap keberhasilan belajar yang dicapainya sehingga siswa tersebut dapat dikategorikan ke dalam lower achiever (siswa dengan pencapaian hasil belajar di bawah potensi yang dimilikinya).

Kesulitan belajar khusus adalah suatu gangguan dalam satu atau lebih dari proses psikologis dasar yang mencakup pemahaman dan penggunaan bahasa ujaran atau tulisan. Gangguan tersebut mungkin menampakkan diri dalam bentuk kesulitan mnedengarkan, berpikir, berbicara, membaca, mengeja, atau berhitung. Batasan tersebut mencakup kondisi-kondisi seperti gangguan perseptual, luka pada otak, disleksia, dan afasia perkembangan.

Kesulitan belajar membaca atau disleksia menurut Bryan dan Bryan (dalam Mercer dalam Mulyono Abdurrahman, 2003) merupakan suatu sindroma kesulitan dalam mempelajari komponenkomponen kata dan kalimat, mengintegrasikan komponen-komponen kata dan kalimat, dan dalam belajar segala sesuatu yang berkenaan dengan waktu, arah, dan masa. Sedangkan menurut Purwandari (2001), disleksia menunjuk pada anak yang tidak dapat membaca, sekalipun penglihatan, pendengaran, intelegensinya normal dan keterampilan bahasanya sesuai. Disleksia ditemukan $80 \%$ dari kelompok individu yang mengalami kesulitan belajar secara khusus. Dengan demikian anak disleksia lebih banyak bila dibanding dengan anak berkesulitan belajar lainya. Sehingga anak disleksia tidak dapat mengikuti pelajaran dengan lancar, akibatnya prestasi belajarnya menjadi rendah yang pada akhirnya sebagian besar mempengaruhi standar penilaian satuan pendidikan.

Oleh karena itu, metode yang sangat dibutuhkan anak disleksia untuk membantu mengatasi kesulitannya adalah memfungsikan seluruh jenis sensorinya, sehingga metode yang memadai dan tepat adalah metode multisensori. Metode multisensori merupakan latihan yang memfungsikan semua sensoris yang masih dimiliki anak untuk mengenal dan mempelajari sesuatu.

Berdasarkan hasil penelitian sebelumnya dapat dimaknai bahwa perlu bagi pendidik atau guru mengetahui dan memahami bagaimana metode multisensori dapat meningkatkan standar penilaian anak dengan kendala disleksia pada sekolah dasar inklusi. Dalam penelitian ini penulis bermaksud mendeskripsikan tentang bagaimana meningkatkan standar penilaian melalui metode multisensori untuk siswa disleksia di SDN Marunda 02 Jakarta Utara berdasarkan pengamatan dan temuan di lapangan.

\section{METODE}

Penelitian ini menggunakan pendekatan kualitatif dengan metode deskriptif. Penelitian kualitatif dengan metode deskriptif adalah metode yang menjelaskan atau mendeskripsikan suatu fakta, data, dan objek penelitian secara sistematis dan sesuai dengan situasi alamiah. Terkait hal yang 
diteliti, hasil penelitian lebih menekankan pada makna dari pada hasil, dan hasil penelitian tidak mengikat serta dapat berubah sesuai dengan kondisi yang dihadapi di lapangan penelitian dan diinterpretasikan dan dituliskan dalam bentuk katakata atau deskriptif berdasarkan fakta di lapangan (Anggito \& Setiawan, 2018).

Peneliti berperan sebagai human instrument (peneliti melakukan penelitiannya sendiri). Pengambilan sampel dan sumber data dilakukan secara purposive sampling (pengambilan sampel berdasarkan atas sebuah pertimbangan yang berfokus pada tujuan tertentu dan peneliti sudah menentukan sebuah kriteria pada pengambilan sampelnya), pengambilan sampel berdasarkan kebutuhan dan sesuai dengan topik penelitian. Teknik pengumpulan data menggunakan wawancara, observasi, dan dokumentasi. Analisis data bersifat kualitatif, dengan menggunakan model Milles \& Huberman. Pemeriksaan keabsahan data, menggunakan triangulasi teknik, meningkatkan ketekunan, dan menggunakan bahan referensi.

Sumber data dalam penelitian adalah subjek mengenai perolehan data yang telah didapat. Datadata yang kemudian dijadikan acuan dalam penelitian ini diambil dari berbagai sumber di antaranya:

1) Sumber Data Primer

Data primer merupakan data yang diperoleh langsung dari subjek yang diteliti, dalam mengumpulkan data primer, peneliti harus kontak atau komunikasi langsung dengan subjek ataupun informan dalam penelitian, maka dari itu, pada penelitian ini sumber data yang didapatkan berasal dari subjek atau informan yang akan diwawancarai dan diobservasi oleh peneliti yang dilakukan langsung di tempat penelitian.

2) Sumber Data Sekunder

Data sekunder merupakan data pelengkap untuk mendukung data primer.

Teknik analisis data yang digunakan dalam penelitian ini adalah menggunakan model Milles dan Huberman, yaitu analisis dalam penelitian dilakukan secara interaktif.

1) Reduksi Data (Reduction)

Peneliti menulis ulang atau merangkum hasil data yang didapatkan pada dari hasil observasi, wawancara, dan dokumentasi. (Milles \& Huberman, 2013)

2) Penyajian Data (Data Display)

Setelah mereduksi data, langkah selanjutnya adalah melakukan penyajian data (display data). Data yang diperoleh dalam penelitian ini disajikan dalam bentuk uraian singkat yang bersifat naratif (dengan teks) (Milles \& Huberman, 2013).

3) Penarikan Kesimpulan (Verification)

Langkah terakhir pada analisis data adalah membuat kesimpulan. Peneliti akan menarik atau membuat kesimpulan dengan memberikan penjelasan dari kegiatan pengambilan data melalui observasi, wawancara, dan didukung oleh dokumentasi. (Milles \& Huberman, 2013). 


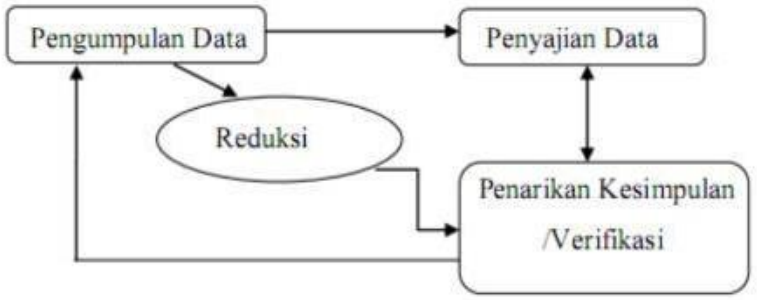

Gambar 1. Analisis Data Interaktif model Hubberman dan Miles

Teknik pemeriksaan keabsahan data yang digunakan oleh peneliti dalam penelitian ini, sebagai berikut:

1) Triangulasi Teknik

Triangulasi teknik digunakan untuk menguji kredibilitas data yang dilakukan dengan cara mengecek data kepada sumber yang sama dengan cara yang berbeda, misalnya peneliti sudah melakukan wawancara, data yang didapatkan melalui wawancara lalu dicek lagi dengan observasi secara langsung, kemudian melakukan dokumentasi (Sugiyono, 2018).

2) Meningkatkan Ketekunan

Meningkatkan ketekunan berarti melakukan pengamatan secara lebih cermat dan berkesinambungan, dengan cara tersebut maka kepastian data yang sudah didapatkan oleh peneliti dan urutan peristiwa akan direkam secara pasti dan sistematis (Sugiyono, 2018).

3) Menggunakan Bahan Referensi

Bahan referensi disini adalah dengan adanya bukti pendukung untuk memperkuat dan membuktikan data yang sudah ditemukan di lapangan penelitian. (Moleong, 2017) .

\section{HASIL DAN PEMBAHASAN}

Dari hasil penelitian didapatkan tiga temuan utama yang dapat dideskripsikan dalam penelitian ini berdasarkan hasil wawancara, observasi dan dokumentasi serta diperkuat dengan kajian teori dari berbagai referensi. Tiga kategori utama tersebut yaitu: pertama metode multisensory mampu meningkatkan Standar Penilaian bagi anak Disleksia, kedua kondisi di SDN Marunda 02 Jakarta Utara, ketiga teknik atau cara mengidentifikasi disleksia.

\section{Metode Multisensori Mampu Meningkatkan Standar Penilaian bagi Anak Disleksia}

Anak disleksia selain mengalami kesulitan dalam memahami komponen kata dan kalimat, umumnya juga mengalami kesulitan menulis. Kesulitan membaca dan menulis selalu ada kaitannya dan tidak dapat dilepaskan dalam hubungannya dengan kesulitan bahasa, karena semua komponen sistem komunikasi yang terintegrasi. Dengan demikian anak disleksia akan mengalami gangguan dalam mengikuti proses pembelajaran di sekolah, karena membaca dan menulis sebagai dasar pemahaman semua mata pelajaran yang diberikan di sekolah. sangat sulit. Sama seperti istilah ketidakmampuan belajar, anak-anak ini berjuang untuk belajar dan sering membutuhkan dukungan tambahan untuk membantu mereka berhasil di sekolah.

Anak-anak penyandang kesulitan belajar tidak melakukannya dengan baik di sekolah telah menarik perhatian dan membingungkan para peneliti dan praktisi di bidang membaca, kognisi, pidato dan pendengaran, neurologi, belajar, visi, audisi, dan pendidikan. Tidak semua anak 
penyandang kesulitan belajar memiliki serangkaian tantangan yang sama. Sebagian besar mengalami kesulitan. Belajar membaca, mengeja, dan menulis. Anak lain mungkin juga memiliki masalah dengan matematika atau dengan menerima informasi dan tugas. Beberapa mengalami kesulitan dengan semua bidang akademik.

Departemen Pendidikan AS (2004) memberi kita definisi berikut:

1. Secara umum Istilah "specific learning disability" atau kesulitan belajar secara spesifik berarti gangguan dalam 1 atau lebih dari proses psikologis dasar yang terlibat dalam pemahaman atau dalam menggunakan bahasa, diucapkan atau ditulis, gangguan yang dapat memanifestasikan dirinya dalam kemampuan yang tidak sempurna untuk mendengarkan, berpikir, berbicara, menulis, mengeja, atau melakukan perhitungan matematika.

2. Gangguan yang termasuk istilah tersebut mencakup kondisi seperti salah persepsi, cedera otak, disfungsi otak minimal, disleksia, dan perkembangan afasia.

Disleksia dianggap sebagai gangguan dalam populasi kesulitan belajar, dan didefinisikan oleh Asosiasi Disleksia Internasional sebagai berikut: salah satu dari beberapa kesulitan belajar yang berbeda, yaitu gangguan konstitusional berbahasa tertentu yang ditandai dengan kesulitan dalam decoding kata tunggal, biasanya mencerminkan pemprosesan fonologis yang tidak cukup. Kesulitan dalam decoding kata tunggal sering tak terduga dalam kaitannya dengan usia dan kemampuan kognitif dan akademik lainnya; mereka tidak termasuk dalam gangguan perkembangan umum atau gangguan sensorik. Disleksia dimanifestasikan dalam kesulitan variabel dengan berbagai bentuk bahasa, selain masalah dengan membaca, masalah mencolok dalam memperoleh kecakapan dalam menulis dan ejaan (Orton Dyslexia Research Committee, 1994).

Kesimpulan utama adalah bahwa anak-anak dengan disleksia memiliki otak yang beroperasi secara berbeda dari otak anak-anak tanpa disleksia (Miller et al, 2003 Rourke, 1991; Willingham, 2008; Willis, 2008). Meskipun orang dengan disleksia memiliki kesulitan dalam pemerolehan bahasa (membaca, ejaan, menulis, dan kesadaran fonologis), banyak yang memiliki kemampuan yang berkembang dengan baik dalam pemecahan masalah visual, spasial, motorik, dan nonverbal (Dickman, 1996).

Proses pembelajaran anak dengan kesulitan belajar membutuhkan beberapa strategi yang disesuaikan pada kondisi anak. Kesulitan membaca merupakan bagian dari kesulitan belajar pada kelompok masalah prestasi akademik. Guru dapat menggunakan metode multisensori untuk membantu siswa disleksia dalam proses pembelajaran. Dipilihnya SD Inklusi sebagai tempat penelitian dengan asumsi bahwa SD tersebut melakukan pembelajaran bagi anak-anak normal dan berkebutuhan khusus secara terpadu. Mereka melakukan pembelajaran secara terpadu tidak terpisah melalui pengintegrasian metode multisensori dengan melibatkan seluruh panca indra dalam proses pembelajaran, hal ini 
dimaksudkan untuk menghilangkan labeling bagi anak berkebutuhan khusus.

\section{Temuan di SDN Marunda 02 Jakarta Utara}

Berdasarkan hasil wawancara terhadap guru, pengamatan peneliti dan dokumentasi di lapangan didapatkan hasil temuan yang terjadi pada Mirza dan Reza siswa kelas dua, SDN Marunda 02 Jakarta Utara. Perkembangan belajar Mirza dan Reza bisa disebut disleksia karena kesulitan belajar pada bidang Bahasa khususnya membaca dan menulis. Penting untuk diingat bahwa tidak semua anak dengan kesulitan belajar memiliki disleksia dan bahwa disleksia sering dianggap sebagai istilah medis, sedangkan kesulitan belajar tertentu digunakan dalam aturan pendidikan. Mirza memiliki kesulitan belajar membaca dan menulis bahkan untuk mengingat dan membedakan bunyi huruf b,d.p dan n,m bahkan mengingat suku kata yang sudah dibacanya sangat sulit,begitupun ketika harus menuliskannya namun Mirza mampu mengikuti instruksi guru dalam hal aktivitas motorik kasar, serta sulit konsentrasi hal ini membuat guru kelasnya sering mengalami kesulitan. Reza pun mengalami disleksia dimana Reza mengalami kesulitan untuk membaca namun Reza mampu untuk berhitung dan mengikuti materi pelajaran lainnya, Reza juga masih mampu menjawab pertanyaan yang berkaiatan dengan cerita yang dibacakan gurunya di sekolah, namun tulisan Reza masih banyak yang kurang atau pun hilang saat dia menulis serta untuk kemampuan berbicara Reza pun masih termasuk sedikit lambat berbicara dengan dapat dilihat bahwa Reza cadel ketika berbicara. Kesulitan Mirza cukup ekstrim sehingga gurunya merasa dia mungkin juga memiliki gangguan tidak dapat konsentrasi.sementara Reza masih mampu diajarkan meskipun harus dengan menggunakan metode yang bervariasi dan melibatkan aktivitas multisensori dengan durasi waktu pembelajaran yang lebih lama jika dibandingkan dengan yang lainnya agar ia mampu membaca dan menulis

Mirza memiliki kecerdasan rata-rata tetapi menghadapi masalah dengan membaca dan menulis. Dia mengalami kesulitan mengatur ideidenya dan sering terganggu. Masalah membacanya begitu parah sehingga ia hampir tidak dapat membaca. Karena hasil akademiknya yang buruk, teman-teman kelasnya berpendapat dia "bodoh." Terlepas dari masalah akademik ini, Mirza unggul dalam satu bidang yang lain yaitu bidang olahraga dan kesenian. Mirza cukup kreatif dan menyukai kegiatan praktik atau demonstrasi langsung. Gurunya berpendapat bahwa Mirza membutuhkan banyak dukungan untuk belajar dikarenakan dua saudara Mirza mengalami ADHD berat dan disekolahkan di SLB, Mirza juga berasal dari keluarga yang berkesulitan Ekonomi. Mirza perlu guru khusus yang kreatif dan inovatif dalam menggunakan media dan metode pembelajaran yang mampu menarik konsentrasi belajarnya karena Mirza sulit untuk berkonsentrasi. untuk mendampinginya dalam belajar membaca dan menulis. Bersama-sama dengan Reza dan Mirza serta guru kelasnya melibatkan komunikasi dan kerjasama dengan orang tua, mencari cara untuk menggunakan kekuatannya dalam olahraga dan kesenian untuk meningkatkan harga dirinya dan membangun lebih banyak dukungan sosial baginya 
dengan teman-temannya.

\section{Solusi yang Dapat Dilakukan Guru dan Orang} Tua

Salah satu bentuk layanan belajar bagi anak berkebutuhan khusus adalah pemberian treatment agar kesulitan dan hambatan belajar yang dialami siswa berkebutuhan khusus dapat diatasi. Harapannya adalah melalui layanan belajar yang tepat siswa yang berkebutuhan khusus dapat mengembangkan secara optimal potensi yang ada pada dirinya. Terdapat berbagai macam treatment yang dapat dilakukan untuk mengatasi kesulitan belajar pada anak disleksia, salah satunya adalah dengan penggunaan media sebagai alat bantu belajar, melibatkan peran seluruh panca indra melalui metode multisensori dalam aktivitas pembelajaran dan remedial, serta peran serta teman sekelasnya dalam membantu menyelesaikan aktivitas pembelajaran anak berkesulitan belajar membaca dan menulis. Peranan media sangat penting dalam pembelajaran mengingat media dapat bermanfaat untuk membantu menyampaikan informasi dari pembelajar kepada subjek ajar secara efektif. Terlebih lagi dengan diterapkannya kurikulum 2013 pembelajaran lebih ditekankan pada metode dan media. Pembelajaran konvensional yang identik dengan metode ceramah mulai ditinggalkan. Hal ini sesuai dengan pernyataan yang menyatakan bahwa di era globalisasi dan informasi penggunaan media pembelajaran tidak hanya sekedar tuntutan tetapi juga merupakan sebuah kebutuhan pembelajaran di era ini hendaknya mengedepankan metode pembelajaran yang mengarah pada keterampilan abad 21. Peran media tidak akan berfungsi dengan maksimal jika metode yang digunakan tidak tepat. Sehingga untuk memaksimalkan fungsi media dalam penanaman konsep suatu bahan pelajaran harus diiringi dengan penggunaan metode pembelajaran yang inovatif dan kreatif juga mampu merangsang siswa yang mengalami kesulitan belajar untuk mau dan termotivasi belajar. Metode multisensori adalah sebuah metode yang menggabungkan dan memaksimalkan penggunaan seluruh fungsi panca indra dalam proses penanaman konsep pembelajaran sehingga mampu menguatkan pemahaman terhadap suatu materi pelajaran dan mampu membantu siswa dalam mengaplikasikannya dalam kehidupan sehari-hari.

Berdasarkan adanya kesulitan belajar pada umumnya berkaitan dengan masalah kemampuan belajar atau masalah akademik; maka ada dua klasifikasi untuk penanganannya yaitu berasal dari persepsi medis dan persepsi psikoedukasional. Dua pendekatan tersebut mengemukakan hal-hal sebagai berikut:

1. Ahli medis beranggapan bahwa kesulitan belajar khusus disebabkan oleh kerusakan, menitikberatkan penanganan atau perawatan melalui obat untuk mengurangi tingkat kesulitan belajar dan gangguan yang diakibatkannya.

2. Psikolog dan ahli-ahli pendidikan beranggapan bahwa penyebab kesulitan belajar adalah karena adanya gangguan dalam keterampilan perseptual motorik.

Setelah menentukan diagnosa gangguan atau kesulitan pada seorang anak, maka bentuk 
penanggulangan/bantuan/intervensi yang dapat diberikan sebagai berikut:

1. Remedial yang bersifat individual merupakan usaha perbaikan yang dilakukan pada fungsi belajar yang terhambat dan dilakukan secara terstruktur, diulang-ulang sampai taraf otomatis serta dilakukan secara berurutan.

2. Tutoring merupakan bantuan yang diberikan langsung pada bidang studi yang terhambat dari siswa yang sudah duduk dibangku sekolah yang dilakukan di luar jam belajar efektif siswa berkesulitan belajar.

3. Kompensasi diberikan bila hambatan yang dimiliki anak berdampak negatif dalam proses pembentukan konsep dirinya.

Untuk penggunaan media dalam pembelajaran disesuaikan dengan situasi dan kondisi masing-masing lingkungan belajar. Aspek yang tidak kalah penting sebagai bahan pertimbangan pemilihan media pembelajaran adalah usia subjek belajar, dalam hal ini adalah siswa. Media pembelajaran yang sesuai dengan karakteristik anak sekolah dasar adalah media gambar. Namun penggunakaan media pun sebaiknya harus memenuhi syarat media yang optimal dimana media yang optimal adalah media yang mampu memaksimalkan fungsi panca indra siswa untuk belajar bereksplorasi dan memahami konsep. Hal ini harus disesuaikan dengan kondisi psikologis siswa Sekolah Dasar yang pada umumnya menyukai dengan hal-hal yang konkrit (Widodo, 2020).

Penggunaan media berbasis digital atau penerapan teknologi juga dapat menjadi pertimbangan untuk membantu memberikan kemudahan pada anak dengan kesulitan belajar. Seperti penelitian yang dilakukan (Pirani et al., 2013). Berkaitan dengan penerapan teknologi juga digagas oleh peneliti (Al-Dababneh \& Al-Zboon, 2020). Hal yang menarik dari hasil penelitian ini adalah penggunaan alat bantu teknologi untuk anak-anak spesifik learning disability yang belajar di sekolah inklusif sangat menjanjikan. Penelitian menunjukkan bahwa peningkatan dalam kesulitan membaca, menulis, mengeja, dan Matematika dimungkinkan bila ada penerapan yang tepat dari perangkat ini, dan guru yang memiliki keyakinan positif dan pelatihan yang memadai terkait alat bantu teknologi dipekerjakan. Penelitian ini menyimpulkan bahwa anak spesifik learning disability yang belajar di sekolah inklusif percaya akan pentingnya penggunaan dan integrasi alat bantu teknologi dalam proses pengajaran. Namun juga terungkap bahwa peserta menggunakan alat bantu teknologi yang sederhana, sehingga dapat disimpulkan bahwa peningkatan pelatihan dan ketersediaan sumber daya akan mendorong penerapan alat bantu teknologi lebih lanjut. Penelitian juga menunjukkan bahwa para guru mengungkapkan optimisme bahwa lebih banyak guru yang berpendidikan akhir-akhir ini akan lebih siap untuk menerapkan alat bantu teknologi.

\section{SIMPULAN}

Metode multisensori dapat digunakan sebagai salah satu model pembelajaran yang dapat mengembangkan kemampuan membaca permulaan anak disleksia. Prosedur pembelajaran dengan metode multisensori dengan memfungsikan 
seluruh jenis sensorinya, yakni melibatkan fungsi perabaan, visual, auditori dan pengucapan. Mulamula anak diminta melihat huruf, meraba dengan menelusuri dan mengucapkan. Metode multisensori dapat melibatkan siswa secara aktif dan interaktif, namun masih membutuhkan pemberian motivasi dari luar oleh guru dan orang tua. Banyak langkah diagnostik yang dapat ditempuh guru, untuk mengambil Alternatif mengatasi kesulitan belajar terlebih dahulu melakukan beberapa langkah penting meliputi: menganalisis hasil diagnosis, menentukan strategi dan bidang kecakapan tertentu yang memerlukan perbaikan, dan menyusun program perbaikan. Setelah langkah-langkah tersebut selesai, barulah pendidik melaksanakan langkah selanjutnya, yakni melaksanakan program perbaikan. Sehingga dengan terlaksananya program perbaikan dengan maksimal mampu meningkatkan standar penilaian bagi sekolah dengan basik pendidikan inklusif.

Salah satu bentuk layanan belajar bagi anak berkebutuhan khusus adalah pemberian treatment dengan pemberian remedial agar kesulitan dan hambatan belajar yang dialami siswa berkebutuhan khusus dapat diatasi. Harapannya adalah melalui layanan belajar yang tepat siswa yang berkebutuhan khusus dapat mengembangkan secara optimal potensi yang ada pada dirinya. Terdapat berbagai macam treatment yang dapat dilakukan untuk mengatasi kesulitan belajar pada anak disleksia, salah satunya adalah dengan penggunaan media sebagai alat bantu belajar yang digunakan dengan menggunakan metode multisensori. Peranan media sangat penting dalam pembelajaran mengingat media dapat bermanfaat untuk membantu menyampaikan informasi dari pembelajar kepada subjek ajar secara efektif.

\section{DAFTAR PUSTAKA}

Kirk, S., Gallagher, J. J., Coleman, M. R., \& Anastasiow, N. (2009). Children Who Are Deaf or Hard of Hearing. In Educating Exceptional Children.

Masri Singarimbun Sofyan Effendi.Metode Penelitian Survey.Jakarta :LP3ES

MAGISTRA: Media Pengembangan Ilmu Pendidikan Dasar Dan Keislaman, 11(1), SELL Journal, 5(1), 55 . https://doi.org/10.31942/mgs.v11i1.3457

Milles, \& Huberman. (2013). Qualitative Data Analysis: A Methods Sourcebook. Los Angeles: SAGE Publications.

Moleong, L. (2017). Metodologi Penelitian Kualitatif. Bandung: PT Remaja Rosdakarya. Dipetik Desember 5, 2019

Moh Nazir. Metode Penelitian.Jakarta. Galia Indonesia, 1988

Mulyono Abdurrahman,Anak Berkesulitan Belajar,(Jakarta: Rineka Cipta,2012)

Nasional, P. K. B. P. dan P. D. P. (2007). Model Kurikulum Bagi Peserta Didik Yang Mengalami Kesulitan Belajar.

Nurdayati Praptiningrum \& Purwandari (2009). Metode Multisensori untuk Mengembangkan Kemampuan Membaca Anak Disleksia di SD Inklusi.Jurnal Penelitian Ilmu Pendidikan, Volume 02, nomor 2, September 2009

Pirani, Z., Molvizadah, V., Abbas Sayyed, M., \& M., S. (2013). E-Learning Framework for Learning Disabled Children. International Journal of Computer Applications, 63(19), 38-42. https://doi.org/10.5120/10577-5703

Yulinda, Erma Suryani,Artikel Kesulitan Belajar(Jakarta:Google sholeer 2004)

Sugiyono. (2018). Metode Penelitian : Kuantitatif, Kualitatif, dan $R \& D$. Bandung: Alfabeta. Dipetik Desember 5, 2019

Suryandari, S. (2020). Jurnal inovasi pendidikan dasar. Jurnal Inovasi Pendidikan Dasar, $4(1), 23-29$. 
Widodo, A. (2020). Analisis Penggunaan Media Gambar Berseri Untuk Meningkatkan Kemampuan Membaca Siswa Disleksia Di Sekolah Dasar. MAGISTRA: Media Pengembangan Ilmu Pendidikan Dasar Dan Keislaman, 11(1),. SELL Journal, 5(1), 55. https://doi.org/10.31942/mgs.v11i1.3457 